\title{
Draft genome sequence of Fusicladium effusum, cause of pecan scab
}

\author{
Clive H. Bock ${ }^{1 *}$, Chunxian Chen ${ }^{1}$, Fahong Yu ${ }^{2}$, Katherine L. Stevenson ${ }^{3}$ and Bruce W. Wood ${ }^{1}$
}

\begin{abstract}
Pecan scab, caused by the plant pathogenic fungus Fusicladium effusum, is the most destructive disease of pecan, an important specialty crop cultivated in several regions of the world. Only a few members of the family Venturiaceae (in which the pathogen resides) have been reported sequenced. We report the first draft genome sequence (40.6 Mb) of an isolate F. effusum collected from a pecan tree (cv. Desirable) in central Georgia, in the US. The genome sequence described will be a useful resource for research of the biology and ecology of the pathogen, coevolution with the pecan host, characterization of genes of interest, and development of markers for studies of genetic diversity, genotyping and phylogenetic analysis. The annotation of the genome is described and a phylogenetic analysis is presented.
\end{abstract}

Keywords: Fusicladium effusum, Venturiacae, Fungal pathogen, Fungicide resistance, Genetic diversity, Pecan, Pecan scab

\section{Introduction}

The pecan scab fungus (Fusicladium effusum [G. Winter]) is an economically important pathogen of pecan (Carya illinoinensis [Wangenh]. K. Koch), on account of its impact on yield and quality of valuable nutmeats [1-3]. Typical lesions resulting from infection by the pathogen are small (generally 1-5 $\mathrm{mm}$ ) blackish and necrotic, forming on leaves, fruit and shoots (Fig. 1a) [4]. F. effusum overwinters as stromata in the lesions on twigs and old shucks in the pecan tree, producing conidia in the spring as temperatures rise, which infect developing leaves and fruit [5]. Both rain and wind play a role in dispersal of conidia, and surface moisture is required for infection $[6,7]$. It is a polycyclic disease, with as little as 7-9 days between infection and sporulation [7], allowing epidemics to develop rapidly when rain is frequent during the spring and summer [8].

Although pecan is native to the US, it is grown commercially elsewhere and the pathogen now occurs not only in the US, but in South America, and South Africa as well [4]. F. effusum reproduces asexually through production of conidia [6], it is pathogenically

\footnotetext{
* Correspondence: clive.bock@ars.usda.gov

${ }^{1}$ Southeastern Fruit and Tree Nut Research Lab, USDA, Agricultural Research

Service, 21 Dunbar Road, Byron, GA 31008, USA

Full list of author information is available at the end of the article
}

diverse [9-12], affecting many different cultivars, and has a history of adapting to novel sources of host resistance [2]. Preliminary molecular studies suggested it is a genetically diverse organism [13, 14], yet no sexual stage has been identified for this fungus. But as the genetic basis of resistance and virulence has not been characterized, progress in breeding resistance is severely hampered. Furthermore, F. effusum has developed insensitivity to several classes of fungicide that are used to manage the pathogen [15].

Some related members of the Class Dothidiomycetes, and the family Venturiacae, in which $F$. effusum resides, have been sequenced [16-21], including Venturia inaequalis (cause of apple scab) and V. pirina (cause of pear scab). These organisms can have impact on plant health, and in some cases animal and human health. These fungal genome sequences provide an opportunity to apply novel genomic and biotechnological tools to develop new solutions to the issues resulting from the interaction of these organisms with their hosts.

With respect to pecan scab, a more thorough understanding of the pathogen and its genetics are needed to develop durable resistance in the pecan host. Sequencing the genome of $F$. effusum will provide a valuable resource to use for identifying various genes of interest, such as those involved in fungicide resistance, those 


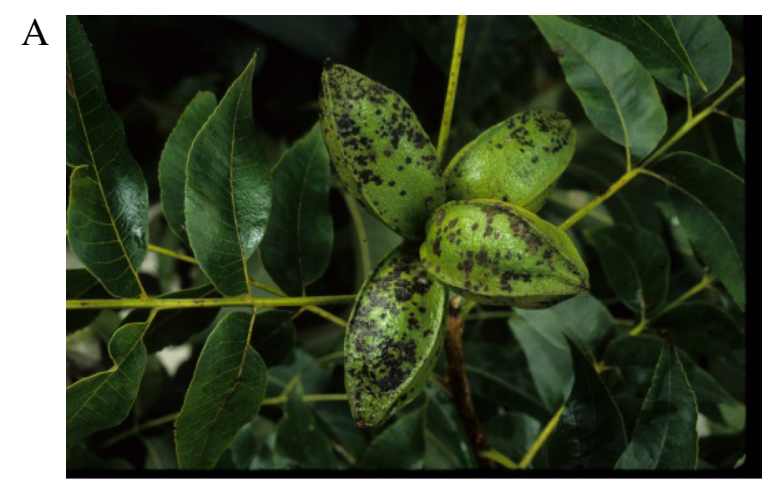

B

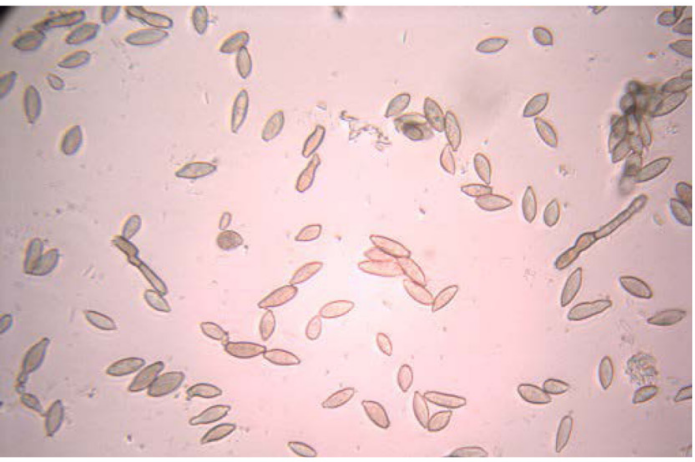

C

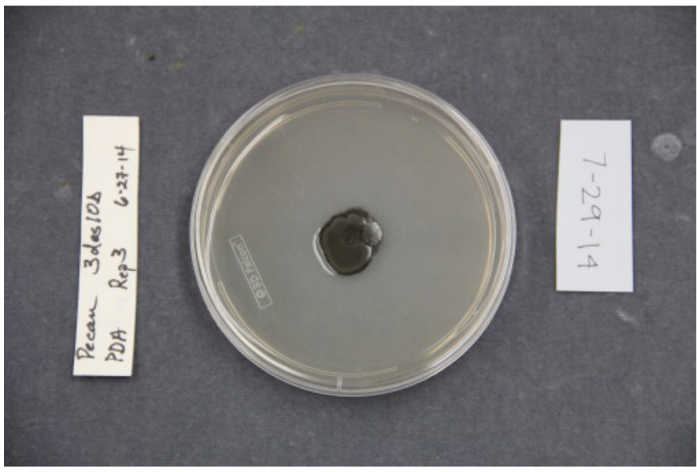

Fig. 1 a Scab symptoms on pecan fruit, caused by Fusicladium effusum. b Conidia of F. effsum (400x). c A 2-week old colony of $F$. effsum growing on PDA

involved in host recognition, mating-type genes, and identification of microsatellites to study genetic diversity (or as markers for other purposes). We describe the first draft genome sequence of $F$. effusum, the characteristics of annotation, and provide a phylogenetic analysis of the taxonomy of the pathogen. The genome sequence will provide an opportunity for new research to gain insight into fundamental aspects of this economically important disease of pecan.

\section{Organism information}

\section{Classification and features}

The sequenced strain of $F$. effusum was isolated from a scab-infected pecan fruit in a 28-y-old tree (cultivar 'Desirable') in July 2010 at the USDA-ARS-SEFTNRL,
Byron, Georgia, US (Table 1). Conidia (Fig. 1b) of F. effusum were scraped from a single lesion on the fruit using a scalpel, and a dilute spore solution prepared in sterile distilled water. Multiple $0.1 \mu \mathrm{L}$ aliquots were spread on the surface of replicate water agar plates (WA, amended with lactic acid $[0.50 \mathrm{~mL} / \mathrm{L}]$, streptomycin $[0.20 \mathrm{~g} / \mathrm{L}]$, tetracycline $[0.05 \mathrm{~g} / \mathrm{L}]$ and chloramphenicol $[0.05 \mathrm{~g} / \mathrm{L}])$. Plates were incubated at $27{ }^{\circ} \mathrm{C}$ for $24 \mathrm{~h}$ under fluorescent light on a $12 / 12 \mathrm{~h}$ day/night cycle. A single germinated spore of $F$. effusum was excised on an agar plug using a scalpel under a microscope (50x), and was transferred to antibiotic-amended potato dextrose agar (PDA [22], amended as for WA) (Fig. 1c).

The fungus resides in the Eukaryota, in the Fungal Kingdom, and is a member of the Phylum Ascomycota (Table 1). It is considered a member of the Class Dothidiomycetes and Family Venturiaceae. Several other economically important plant pathogens are members of the Dothidiomycetes, including Septoria leaf blotch of wheat (Zymoseptoria tritici $=$ Mycosphaerella graminicola), rice blast, (Magnaprthe grisea) and apple scab (Venturia inaequalis). $F$. effusum has been classified based on its host range, morphology and molecular characteristics (particularly the cytochrome b [23] and ITS region [24]). In the current report, the phylogenetic relationship of $F$. effusum to other Ascomycota species based on the 18S rRNA genes shows that it is most closely related to members of the family Venturiaceae, genera Fusicladium and Venturia (Fig. 2). The $18 \mathrm{~S}$ rRNA gene was located on contig0312 and a 224 bp portion aligned with the sequences from the other fungi was used for the analysis. The phylogenetic analysis was performed using nearest neighbor joining method in CLUSTALX2 [25] with node values based on 1000 replicates. The phylogenetic tree was drawn by TreeView [26]. Members from other genera in the Dothidiomycetes (in which the family Venturiaceae resides) were included as outgroups.

\section{Genome sequencing information \\ Genome project history}

The genome of $F$. effusum described here was sequenced in 2011 at the ICBR core facility of the University of Florida, Gainesville, Florida, US. The genome was assembled and annotated at the bioinformatics unit at the same location. The project is deposited in Genbank under Bioproject ID PRJNA285422, and the draft assembly and annotation of the isolate of $F$. effusum described in this article is deposited in the same location. The project data is summarized in Table 2 . The project information is in compliance with MIGS version 2.0 [27].

\section{Growth conditions and genomic DNA preparation}

The isolate of $F$. effusum was cultured on antibioticamended potato dextrose agar (amended as for WA, 
Table 1 Classification and general features of Fusicladium effusum designation [37]

\begin{tabular}{|c|c|c|c|}
\hline MIGS ID & Property & Term & Evidence code $^{a}$ \\
\hline & Classification & Domain Fungi & TAS $[4,24]$ \\
\hline & & Phylum Ascomycota & TAS $[4,24]$ \\
\hline & & Class Dothidiomycetes & TAS $[4,24]$ \\
\hline & & Order Pleosporales & TAS $[4,24]$ \\
\hline & & Family Venturiaceae & TAS $[4,24]$ \\
\hline & & Genus Fusicladium & TAS $[4,24]$ \\
\hline & & Species Fusicladium effusum & TAS $[4,24]$ \\
\hline & Gram stain & $\mathrm{n} / \mathrm{a}$ & $\mathrm{n} / \mathrm{a}$ \\
\hline & Cell shape & Mycelium with septae & TAS $[4,24]$ \\
\hline & Motility & Non-motile & $\operatorname{TAS}[4,24]$ \\
\hline & Sporulation & Conidia on conidiophores & $\operatorname{TAS}[4,6]$ \\
\hline & Temperature range & Mesophilic $\left(10-35^{\circ} \mathrm{C}\right)$ & TAS [7] \\
\hline & Optimum temperature & $15-25^{\circ} \mathrm{C}$ & TAS [7] \\
\hline & pH range; Optimum & Not reported & $\mathrm{n} / \mathrm{a}$ \\
\hline & Carbon source & Not reported & $\mathrm{n} / \mathrm{a}$ \\
\hline MIGS-6 & Habitat & Arboreal & TAS [4] \\
\hline MIGS-22 & Oxygen requirement & Aerobic & TAS $[4,24]$ \\
\hline MIGS-15 & Biotic relationship & Free living & TAS [4] \\
\hline MIGS-14 & Pathogenicity & Pathogenic & TAS [4] \\
\hline MIGS-4 & Geographic location & Byron, Georgia, USA & TAS \\
\hline MIGS-5 & Sample collection & July 2010 & TAS \\
\hline MIGS-4.1 & Latitude & $32.652^{\circ} \mathrm{N}$ & TAS \\
\hline MIGS-4.2 & Longitude & $83.739^{\circ} \mathrm{W}$ & TAS \\
\hline MIGS-4.4 & Altitude & 156 m & TAS \\
\hline
\end{tabular}

a Evidence codes - IDA inferred from direct assay, TAS traceable author statement (i.e., a direct report exists in the literature), NAS non-traceable author statement (i.e., not directly observed for the living, isolated sample, but based on a generally accepted property for the species, or anecdotal evidence). Evidence codes as for the Gene Ontology project [37]

described above) and incubated for 3 weeks at $25{ }^{\circ} \mathrm{C}$ (12 h light/12 h dark), at which time the DNA was extracted from the sample using a ZymoResearch DNA extraction kit (ZymoResearch, Irvine, CA), following a slightly modified protocol for DNA extraction from fungi [23]. A Fastprep FP120 (Savant Instruments, Holbrook, NY) was used to lyse the mycelium. Once obtained, the DNA was quantified using a Nanodrop spectrophotometer (Nanodrop Products, Wilmington, DE) and stored in TE buffer at $-20^{\circ} \mathrm{C}$.

\section{Genome sequencing and assembly}

The genome was sequenced using 454 GS-FLX Titanium and Illumina Genome Analyzer IIx sequencing platforms. Two stages of assembly were performed to ensure the accuracy and quality of the contigs. The 454 reads were cleaned by masking repeats and removing primers and/or adaptors used in library preparation. The Illumina reads were cleaned using 'cross_match' in Phrap [28] and the cleanup module in PTA V3.0.0 [29] to remove low-quality ( $<20$ phred-like score) and short $(<40 \mathrm{bp})$ reads. These cleaned Illumina reads were assembled with multiple trials (a series of $\mathrm{k}$-mers from $30 \mathrm{bp}$ to $75 \mathrm{bp}$ ) using ABySS V1.2.6 [30]. The assembled contigs with $\geq 2,000$ bp from ABySS were computationally chopped into 800-bp fragments (with 200 bp overlapping between two adjacent fragments) and further assembled with the cleaned 454 reads using Newbler V2.3 (454 Life Science), to generate the final contigs and scaffolds. A total of 11,959 contigs and 545 scaffolds (average size $=74.4 \mathrm{~Kb}$; total size $=40.6 \mathrm{Mb}$ ) were assembled from over 69.2 million clean reads $(7.1 \mathrm{~Gb})$. The largest scaffold was $>1.1 \mathrm{Mb}$. There were 3,113 large contigs ( $\geq 500 \mathrm{bp}$ ), totaling $>40.1 \mathrm{Mb}$ which is typical for a genome in the Ascomycota (36.9 Mb, [31]), and not dissimilar to that reported for $V$. pirina [16] and $V$. inaequalis [32]. The $170 \times$ genome coverage indicated that $\geq 95 \%$ of the genome $(42.6 \mathrm{Mb})$ was covered, based on a comparison of reads from high-quality genome sequences [33]. 


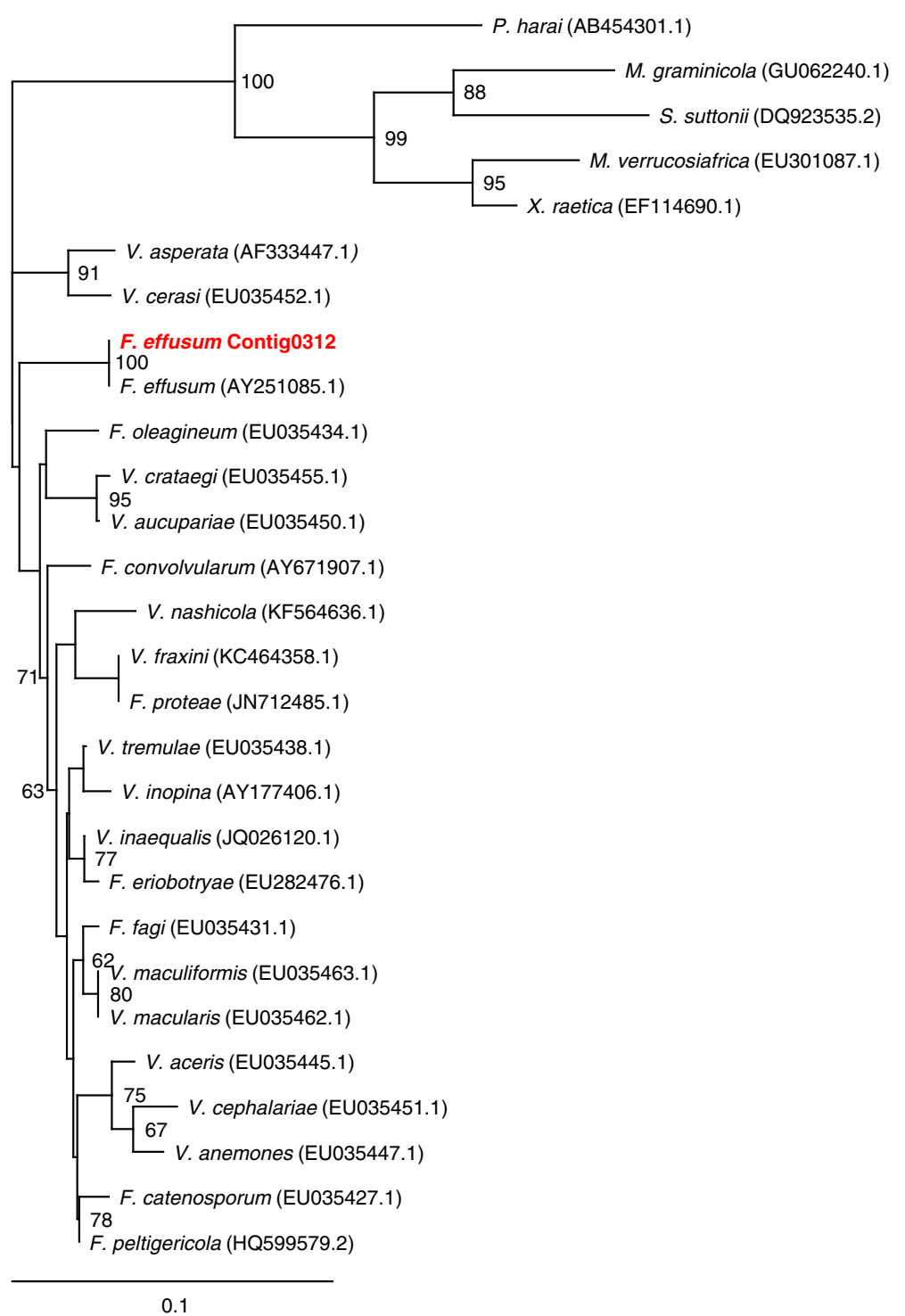

Fig. 2 The phylogenetic position of Fusicladium effusum in comparison with other related fungal species. The tree was developed based on the $18 \mathrm{~S}$ rRNA gene of the sequenced isolate of F. effusum, an accession of the 18S rRNA gene of another $F$. effusum isolate, and accessions of other members of the family Venturiaceae (genera Fusicladium and Venturia) and an outgroup with representatives from other Ascomycota from the class Dothidiomyectes (Phyllosticta harai, Staniwardia suttonii, Mycosphaerella graminicola and M. verrucosiafricana). The sequence data were subjected to phylogenetic analysis using CLUSTALX2 [25] and MEGA5 [38] to construct a nearest neighbor joining tree (numbers adjacent to branches are support values from 1000 bootstraps). The tree is drawn to scale in TreeView [26], with branch lengths measured in the number of substitutions per site - 0.1 on the scale bar represents 4 substitutions in $100 \mathrm{bp}$. The evolutionary history was inferred from 224 aligned characters. The GenBank accession numbers for each stain are shown in parenthesis

\section{Genome annotation}

$A b$ initio gene prediction with the FGENESB package (Softberry Inc.) predicted 50,192 ORFs from the 3,113 large contigs, including 18,501 RNA ORFs (36.9\%), which was substantially higher than might be expected for this type of organism. For example, only 6,299 peptides were predicted in the genome of $V$. pirina [34], and 13,233 genes in that of $V$. inaequalis [32]. The draft genome sequence of $F$. effusum was somewhat fragmented and an elevated count of small contigs (a total of
11,959) likely led to prediction of multiple ORFs from some genes that were divided among different contigs. Thus the gene count prediction of this draft genome is tentative. To obtain a more accurate perspective on the functional genes $[35,36]$, we further annotated the ORFs through BLAST at $1 \mathrm{e}-4$ to three genomes, (Phaeosphaeria nodorum, Pyrenophora teres, and Saccharomyces cerevisiae), in which only 13,897 ORFs were identified. We also used BLAST against three generic genomic databases (NCBI nr, COG and KEGG), in 
Table 2 Project information

\begin{tabular}{|c|c|c|}
\hline MIGS ID & Property & Term \\
\hline MIGS-31 & Finishing quality & High quality draft \\
\hline MIGS-28 & Libraries used & $\begin{array}{l}\text { 454: paired end sequences with 450b } \\
\text { insert; Illumina: } 1 \text { kb paired-end library }\end{array}$ \\
\hline MIGS-29 & $\begin{array}{l}\text { Sequencing } \\
\text { platforms }\end{array}$ & $\begin{array}{l}\text { Illumina Genome Analyzer IIx/454 } \\
\text { GS-FLX Titanium }\end{array}$ \\
\hline MIGS-31.2 & Fold coverage & $170 x$ \\
\hline MIGS-30 & Assemblers & $\begin{array}{l}\text { ABySS V1.2.6/Newbler V2.3/Phrap/ } \\
\text { Paracel Transcript Assembler V3.0.0 }\end{array}$ \\
\hline \multirow[t]{6}{*}{ MIGS-32 } & $\begin{array}{l}\text { Gene calling } \\
\text { method }\end{array}$ & $\begin{array}{l}\text { FGENESB/COG/KEGG } \\
\text { (Also BLAST search (NCBI tblastx) } \\
\text { against the NCBI NR (non-redundant) } \\
\text { database and the genome sequences } \\
\text { of Phaeosphaeria nodorum, Pyrenophora } \\
\text { teres, and Saccharomyces cerevisiae) }\end{array}$ \\
\hline & Locus tag & Locus Tags not reported \\
\hline & Genbank ID & GDCP00000000 \\
\hline & $\begin{array}{l}\text { Genbank date of } \\
\text { release }\end{array}$ & 2015-06-01 \\
\hline & GOLD ID & Not established in GOLD \\
\hline & BIOPROJECT & PRJNA285422 \\
\hline \multirow[t]{2}{*}{ MIGS-31 } & $\begin{array}{l}\text { Source material } \\
\text { identifier }\end{array}$ & Not reported \\
\hline & Project relevance & $\begin{array}{l}\text { Biotechnology/mycology/disease } \\
\text { control }\end{array}$ \\
\hline
\end{tabular}

which there was a total of 18,139 hits. At this less stringent e-value, both numbers are only slightly higher than might be expected in a fungal genome; therefore we conclude that the ORFs identified are likely representative of the functional genes in F. effusum.

\section{Genome properties}

The draft genome sequence was based on an assembly of 545 scaffolds amounting to 40,096,772 bp, with a G + C content of $48 \%$. Of the total predicted ORFs, 17,935 had hits in the $\mathrm{nr}$ database, 5,263 were assigned to COGs (12.1\%), and 1,580 ORFs in KEGG databases, respectively. It appeared the predicted number of ORFs by FGENESB was not in an expected range of gene numbers predicted in other fungal genomes. Checking known genes, some were incorrectly predicted into multiple ORFs by FGENESB (data not shown). On the other hand, some of the ORFs without hits in the nr database might not be new functional genes. Transcriptome sequences of the genome could be used to improve the $a b$ initio gene prediction in the future. These and other properties of the $F$. effusum genome are summarized in Table 3. The distribution of genes into COG functional categories is presented in Table 4. Of the 5,263 proteins, the most abundant COG category was "General function prediction only" (862 proteins) followed by "Carbohydrate transport and metabolism" (658 proteins), "Amino
Table 3 Nucleotide and gene count levels of the genome

\begin{tabular}{llc}
\hline Attribute & Genome (total) & \\
\cline { 2 - 3 } & Value & \% of total \\
\hline Genome size (Mbp) & $\sim 40.1$ & \\
DNA coding (bp) & $23932944(/ 40096772)$ & 59.7 \\
DNA G + C content (bp) & $19203566(/ 40096772)$ & 48 \\
DNA scaffolds & 545 & \\
Total genes ${ }^{a}$ & 50192 & \\
Protein coding genes & $18501(/ 50192)$ & 36.9 \\
RNA genes & Not reported & \\
Pseudo genes & Not reported & \\
Genes in internal clusters & Not reported \\
Genes with function prediction & Not reported \\
Genes assigned to COGs & 5263 (/50192) \\
Genes with Pfam domains & Not reported \\
Genes with signal peptides & Not reported \\
Genes with transmembrane helices & Not reported \\
CRISPR repeats & Not reported
\end{tabular}

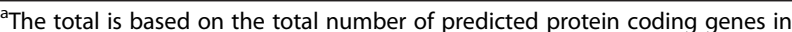
the annotated genome using FGENESB

acid transport and metabolism" (468 proteins), "Lipid transport and metabolism" (364 proteins), "Translocation, ribosomal structure and biogenesis" (323), and "Energy production and conversion" (308 proteins).

\section{Insights from the genome sequence}

The genome provides a useful resource for identifying genes of interest in F. effusum. Several genes of interest were annotated, including many from the family of P450 genes (of specific interest are the full-length CYP51A (contig 00394) and CYP51B (contig 00058) genes, which are identified in the genome and may be involved in resistance to the dimethyl inhibitors (DMIs) fungicides). Evidence of the mating type gene was also found (putatively MAT-2, Contig 00032), which will be useful as $F$. effusum is currently known only by its asexual stage (conidia), so mating type gene identification can pave the way to establishing existence of a sexual stage. An analysis has also demonstrated that the genome is a rich resource to obtain microsatellite markers with different motif characteristics for studies of pathogen diversity, and to develop as markers for other genetic studies. Furthermore, the phylogenetic analysis presented confirms the close relationship of F. effusum to other members of the Venturiacae and previous observations on the taxonomic relationships among these members of the Ascomycota.

\section{Conclusions}

The annotated ORFs may represent partial or full lengths of most functional genes in the F. effusum genome and 
Table 4 Number of genes associated with general COG functional categories

\begin{tabular}{|c|c|c|c|}
\hline Code & Value & $\%$ age & Description \\
\hline J & 323 & 6.14 & Translation, ribosomal structure and biogenesis \\
\hline A & 27 & 0.51 & RNA processing and modification \\
\hline K & 175 & 3.33 & Transcription \\
\hline L & 265 & 5.04 & Replication, recombination and repair \\
\hline B & 39 & 0.74 & $\begin{array}{l}\text { Chromatin structure and dynamics; } \mathrm{K} \\
\text { Transcription }\end{array}$ \\
\hline D & 70 & 1.33 & $\begin{array}{l}\text { Cell cycle control, cell division, chromosome } \\
\text { partitioning }\end{array}$ \\
\hline V & 74 & 1.41 & Defense mechanisms \\
\hline $\mathrm{T}$ & 142 & 2.70 & Signal transduction mechanisms \\
\hline M & 131 & 2.49 & Cell wall/membrane/envelope biogenesis \\
\hline N & 7 & 0.13 & Cell motility; T Signal transduction mechanisms \\
\hline U & 87 & 1.65 & $\begin{array}{l}\text { Intracellular trafficking, secretion, and vesicular } \\
\text { transport }\end{array}$ \\
\hline O & 353 & 6.71 & $\begin{array}{l}\text { Posttranslational modification, protein turnover, } \\
\text { chaperones }\end{array}$ \\
\hline C & 308 & 5.85 & Energy production and conversion \\
\hline G & 658 & 12.50 & Carbohydrate transport and metabolism \\
\hline $\mathrm{E}$ & 468 & 8.89 & Amino acid transport and metabolism \\
\hline $\mathrm{F}$ & 129 & 2.45 & Nucleotide transport and metabolism \\
\hline H & 143 & 2.72 & Coenzyme transport and metabolism \\
\hline । & 364 & 6.92 & Lipid transport and metabolism \\
\hline$P$ & 213 & 4.05 & Inorganic ion transport and metabolism \\
\hline Q & 207 & 3.93 & $\begin{array}{l}\text { Secondary metabolites biosynthesis, transport } \\
\text { and catabolism; }\end{array}$ \\
\hline R & 862 & 16.38 & General function prediction only \\
\hline S & 156 & 2.96 & Function unknown \\
\hline - & - & - & Not in COGS \\
\hline
\end{tabular}

The total is based on the total number of protein coding genes in the genome

can be used as a new resource for developing molecular markers for genetic diversity studies, and for other research in biology, ecology and phylogenetics, and for research into host/pathogen coevolution.

\section{Acknowledgments}

The research was supported through USDA-ARS project no. 6042-21220-012-00. The authors thank Dr. Mike Hotchkiss for help with sample collection, and Minling Zhang for technical support (USDA-ARS, Byron, GA). This article reports the results of research only. Mention of a trademark or proprietary product is solely for the purpose of providing specific information and does not constitute a guarantee or warranty of the product by the US Department of Agriculture and does not imply its approval to the exclusion of other products that may also be suitable.

\section{Authors' contributions}

CB collected the isolate and extracted the DNA. CC performed the phylogenetic analysis and some of the other bioinformatics. CB, CC, FY, KS and BW worked on the sequencing, data analysis and drafted the manuscript. All authors read and approved the final version of the manuscript.

\section{Competing interests}

The authors declare that they have no competing interests.

\section{Author details}

${ }^{1}$ Southeastern Fruit and Tree Nut Research Lab, USDA, Agricultural Research Service, 21 Dunbar Road, Byron, GA 31008, USA. ${ }^{2}$ Interdisciplinary Center for Biotechnology Research, University of Florida, 2033 Mowry Road, Gainesville, FL 32610, USA. ${ }^{3}$ Department of Plant Pathology, University of Georgia, 2360 Rainwater Rd., Tifton, GA 31793, USA.

Received: 19 November 2015 Accepted: 24 May 2016

Published online: 03 June 2016

\section{References}

1. Gottwald TR, Bertrand PF. Effects of an abbreviated pecan disease control program on pecan scab disease increase and crop yield. Plant Dis. 1988;72: 27-32.

2. Goff WD, McVay JR, Gazaway WS. Pecan production in the Southeast, Alabama cooperative extension system circular ANR-459. Auburn: University Auburn; 1996. p. 222.

3. Stevenson KL, Bertrand PF. Within-season dynamics of yield loss due to pecan scab fruit infections. Phys Chem Chem Phys. 2002;91:S85.

4. Bock CH. Fusicladium effusum. Wallingford: Crop Protection Compendium Datasheet, Commonwealth Agriculture Bureau International; 2013. http:// www.cabi.org/isc/datasheet/13719. Accessed 26 May 2016.

5. Demaree JB. Pecan scab with special reference to sources of the early spring infections. J Agr Res. 1924;28:321-9.

6. Gottwald TR, Bertrand PF. Patterns of diurnal and seasonal airborne spore concentrations of Fusicladium effusum and its impact on a pecan scab epidemic. Phys Chem Chem Phys. 1982;72:330-5.

7. Gottwald TR. Influence of temperature, leaf wetness period, leaf age, and spore concentration on infection of pecan leaves by conidia of Cladosporium caryigenum. Phys Chem Chem Phys. 1985;75(2):190-4.

8. Gottwald TR, Bertrand PF. Effect of time of inoculation with Cladosporium caryigenum on pecan scab development and nut quality. Phys Chem Chem Phys. 1983;73(5):714-8.

9. Demaree JB, Cole JR. Behavior of Cladosporium effusum (Wint.)Demaree on some varieties of pecan. J Agr Res. 1929;38:363-70.

10. Converse RH. Physiologic specialization in Fusicladium effusum and its evaluation in vitro. Phys Chem Chem Phys. 1960;50:527-31.

11. Graves $\mathrm{CH}$. Breeding for pecan scab resistance. Proc Southeast Pecan Growers Assoc. 1975;61:168-71.

12. Conner PJ, Stevenson KL. Pathogenic variation of Cladosporium caryigenum isolates and corresponding differential resistance in pecan. HortSci. 2004;39: 553-7.

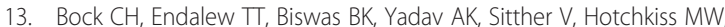
Stevenson KL, Wood BW. A comparison of UP-PCR and RAPD markers to study genetic diversity of the pecan scab fungus (Fusicladium effusum $\mathrm{G}$. Winter). Forest Path. 2014;44:266-75.

14. Bock CH, Stevenson KL, Arias RS, Wood BW. Genetic diversity and population structure of Fusicladium effusum on pecan in the U.S.A. Plant Dis. 2014;98:916-23.

15. Seyran M, Brenneman TB, Stevenson KL. A rapid method to monitor fungicide sensitivity in the pecan scab pathogen, Fusicladium effusum. Crop Prot. 2010;29(11):1257-63.

16. Jones D. 2014. Venturia pyrina ICMP 11032 genome sequencing. NCBIGenBank, Bioproject, accession no. PRJNA232087. http://www.ncbi.nlm.nih. gov/bioproject/?term=Venturia+pyrina. Accessed 26 May 2016.

17. Deng C. 2014. Venturia inaequalis genome sequencing. NCBI-GenBank, Bioproject 261633, accession no. PRJNA261633. http://www.ncbi.n/m.nih gov/bioproject/261633. Accessed 26 May 2016.

18. Kroll D. 2014. Resequencing of ST99CH3D7. Bioproject, Accession number: PRJNA290690. http://www.ncbi.nlm.nih.gov/ bioproject?LinkName=biosample_bioproject\&from_uid=1882120. Accessed 26 May 2016

19. Studholme D. 2015. Microbe sample from Zymoseptoria tritici IPO323. Bioproject, accession no. PRJNA296417. http://www.ncbi.nlm.nih.gov/ bioproject/296417. Accessed 26 May 2016.

20. Ng KP, Yew SM, Chan CL, Soo-Hoo TS, Na SL, Hassan H, Ngeow YF, Hoh CC, Lee, K-W, Yee, W-Y. Sequencing of Cladosporium sphaerospermum, a Dematiaceous Fungus Isolated from Blood Culture. Eukaryot Cell. 2012;11(5): $705-6$. 
21. Nierman WC, Yu J, Federova-Abrams ND, Losada L, Cleveland TE, Bhatnaga JW, Bennett JW, Payne GA. Genome sequence of Aspergillus flavus NRRL 3357, a strain that causes aflatoxin contamination of food and feed. Genome Ann. 2015. doi:10.1128/genomeA.00168-15.

22. Barnes $\mathrm{GL}$. Growth response of the pecan scab fungus, Fusicaldium effusum, on various common and exotic agar media. Oklahoma Agricultural Experiment Station Technical Bulletin, T-110. 1964.

23. Seyran M, Nischwitz C, Lewis K, Gitaitis RD, Brenneman TB, Stevenson KL. Phylogeny of the pecan scab fungus Fusicladium effusum G. Winter based on the cytochrome b gene sequence. Mycol Prog. 2010;9(2):305-8.

24. Schubert K, Ritschel A, Braun U. A monograph of Fusicladium s.lat. (hyphomycetes). Schlechtendalia. 2003;9:1-132.

25. Larkin MA, Blackshields G, Brown NP, Chenna R, McGettigan PA, McWilliam H, et al. Clustal W and clustal X version 2.0. Bioinformatics. 2007;23(21):2947-8.

26. Page RDM. TreeView: An application to display phylogenetic trees on personal computers. Computer Applic Biosci. 1996;12(4):357-8.

27. Field D, Garrity G, Gray T, Morrison N, Selengut J, Sterk P, Tatusova T, Thomson $\mathrm{N}$, Allen MJ, Angiuoli SV, et al. The minimum information about a genome sequence (MIGS) specification. Nat Biotechnol. 2008;26(5):541-7.

28. Gordon D, Desmarais C, Green P. Automated finishing with autofinish. Genome Res. 2001;11(4):614-25. doi:10.1101/gr.171401.

29. Boysen C, Pao SS, Qian J, Smith CP, Zhu L, Borkowski A. Paracel Transcript Assembler: Identification of splice variants for gene discovery and gene expression profiling. Transcriptome 2002: From functional genomics to systems biology. March 10-13, 2002, Seattle, Washington, USA. P05. http:// web.ornl.gov/sci/techresources/meetings/transcriptome2002/p05.shtml. Accessed 26 May 2016.

30. Birol I, Jackman SD, Nielsen CB, Qian JQ, Varhol R, Stazyk G, Morin RD, Zhao Y, Hirst M, Schein JE, Horsman DE, Connors JM, Gascoyne RD, Marra MA, Jones SJ. De novo transcriptome assembly with ABySS. Bioinf. 2009;25(21): 2872-7. doi:10.1093/bioinformatics/btp367.

31. Mohanta TK, Bae H. The diversity of fungal genome. Biol Proceed Online. 2015;17:8. doi:10.1186/s12575-015-0020-z.

32. Deng C, Bowen J, Plummer K. Venturia inaequalis (information tab), JGI mycocosm - the fungal genomics resource. 2016. http://genome.jgi.doe. gov/Nenin1/Nenin1.info.html. Accessed 26 May 2016.

33. Chu TC, Lu CH, Liu TL, Lee GC, Li WH, Shih ACC. Assembler for de novo assembly of large genomes. Proc Natl Acad Sci U S A. 2013;110(36):E3417-24. doi:10.1073/pnas.1314090110.

34. Cooke IR, Jones D, Bowen JK, Deng C, Faou P, Hall NE, Jayachandran V, Liem M, Taranto AP, Plummer KM. Proteogenomic analysis of the Venturia pirina (pear scab fungus) secretome reveals potential effectors. J Prot Res. 2014; 13:3635-44.

35. Mavromatis K, Ivanova N, Barry K, Shapiro H, Goltsman E, McHardy AC, AC Rigoutsos I, Salamov A, Korzeniewski F, Land M, Lapidus A, Grigoriev I, Richardson P, Hugenholtz P, Kyrpides NC. Use of simulated data sets to evaluate the fidelity of metagenomic processing methods. Nature Meth. 2007; 4(6):495-500. doi:10.1038/nmeth1043.

36. Zhu W, Lomsadze A, Borodovsky M. Ab initio gene identification in metagenomic sequences. Nucl Acids Res. 2010;38(12), e132. doi:10. 1093/nar/gkq275

37. Ashburner M, Ball CA, Blake JA, Botstein D, Butler H, Cherry JM, et al. Gene Ontology: tool for the unification of biology. Nat Genet. 2000;25(1):25-9.

38. Tamura K, Peterson D, Peterson N, Stecher G, Nei M, Kumar S. MEGA5: molecular evolutionary genetics analysis using maximum likelihood, evolutionary distance, and maximum parsimony methods. Mol Biol Evol. 2011:28:2731-9.

\section{Submit your next manuscript to BioMed Central and we will help you at every step:}

- We accept pre-submission inquiries

- Our selector tool helps you to find the most relevant journal

- We provide round the clock customer support

- Convenient online submission

- Thorough peer review

- Inclusion in PubMed and all major indexing services

- Maximum visibility for your research

Submit your manuscript at www.biomedcentral.com/submit
( ) BioMed Central 